\title{
ANALYSIS OF PRECIPITATION TRENDS IN GILGIT-BALTISTAN (GB), PAKISTAN
}

M. Raza*

Department of Physics, Karakorum International University Gilgit-Baltistan

\section{ABSTRACT}

This article explores seasonal as well as annual trends of precipitation in Gilgit-Baltistan (GB) Pakistan over the period between 1980 and 2012. For the analysis of precipitation trends, non-parametric Mann-Kendall and Sen's tests were applied. The assessment of precipitation data showed an annual increasing trend of precipitation in GB although this trend is not statistically significant. Seasonal analysis revealed least amount of precipitation occurs in the autumn season which is becoming drier. Trend analysis showed an increasing trend of precipitation in the other three seasons (winter, Spring and summer). The study revealed that the precipitation at Gupis is increasing significantly in winter, spring and summer seasons.

KEYWORDS: Precipitation, Mann-Kendall, significant, Gilgit-Baltistan.

*Corresponding author: (Email: raza.physics@kiu.edu.pk)

\section{INTRODUCTION}

Winter and summer are the two major rainy/precipitation seasons in Pakistan. In winter, the mid-latitude westerly waves move across the lower latitudes and their troughs generally extend down to $35^{\circ} \mathrm{N}$, and sometimes even further south. Under the influence of westerly waves as well frontal system, the northern parts of Pakistan receive substantial rainfall over low elevation and snow fall at high elevation areas in the winter season. In Pakistan the total annual precipitation ranges from $500 \mathrm{~mm}$ to $800 \mathrm{~mm}$. The northern half of the country receives handsome amount of precipitation in both winter and summer, but the southern half receives hardly $50 \%$ of the amount received in the north [1].

Solid precipitation over the northern mountains melts in early summer and maintains sustainable river flow for power generation and irrigation before the onset of summer monsoon.
In addition to this precipitation, winter rain bearing systems yield substantial rainfall in submountainous and low elevation plains [2].

The northern part especially GB is host to the world's largest glaciers and is the major water resource the River Indus, the leading river of the country [3]. Changing trends of precipitation and extreme events in GB bring floods in the Indus on large scale and damage the population living down the country. In context of climate change and disaster management, it is therefore important to understand the precipitation trends. The aim of this study is to analyze the recent trends of annual and seasonal precipitation in GB.

\section{DATA AND STUDY AREA}

To carry out precipitation assessment, daily precipitation data over the period 1980 - 2012 from the six weather stations situated in GB were obtained from Pakistan Meteorological Department (PMD). Fig. 1 and Table 1 show the 
specific locations of the six stations and data period of precipitation used in this study. Using this dataset monthly, seasonal and annual total precipitation was calculated, and trend analysis was also performed.

For all the six stations homogeneity analysis of the dataset was performed on monthly total precipitation. Graphical analysis was carried out to check the homogeneity of the dataset. The monthly totals of all the six stations have been used to calculate the regional average and the regional precipitation series.

\section{METHODOLOGY}

Monthly total precipitation was calculated from the daily precipitation data. These monthly totals were used to calculate the annual and seasonal precipitation. The regional precipitation index was developed using monthly precipitation of the six weather stations in GB. The stepwise methodology of the study is given in Fig.2.

Table 1: Details of Stations

\begin{tabular}{|l|l|l|l|l|}
\hline $\begin{array}{l}\text { General } \\
\text { Location }\end{array}$ & $\begin{array}{l}\text { Station } \\
\text { Name }\end{array}$ & Latitude & Longitude & $\begin{array}{l}\text { Average } \\
\text { Altitude } \\
\text { a.s.l. } \\
\text { (meters) }\end{array}$ \\
\hline \multirow{2}{*}{ GB } & Astor & $35 \circ 20^{\prime}$ & $74 \circ 54^{\prime}$ & 2168 \\
\cline { 2 - 5 } & Bunji & $35 \circ 40 /$ & $74 \circ 38 /$ & 1372 \\
\cline { 2 - 5 } & Chilas & $35 \circ 25^{\prime}$ & $74 \circ 06 /$ & 1251 \\
\cline { 2 - 5 } & Gilgit & $35 \circ 55^{\prime}$ & $74 \circ 20^{\prime}$ & 1460 \\
\cline { 2 - 5 } & Gupis & $36 \circ 10^{\prime}$ & $73^{\circ} 24^{\prime}$ & 2155 \\
\cline { 2 - 5 } & Skardu & $35^{\circ} 18 /$ & $75^{\circ} 41^{\prime}$ & 2210 \\
\hline
\end{tabular}

\subsection{Mann-Kendall test}

The Mann-Kendall test, which is a nonparametric; therefore, data outliers do not affect the results $[4,5,6,7]$. It was applied to the long-term data in this study to detect statistically significant trends. In this test, the null hypothesis $\left(\mathrm{H}_{0}\right)$ was that there has been no trend in precipitation over time; the alternate hypothesis $\left(\mathrm{H}_{1}\right)$ was that there has been a trend (increasing/decreasing) over time. For the assessment of changes in magnitude of precipitation we used Sen's test method. The mathematical equations for calculating MannKendall statistics S, V(S) and standardized test statistics Z are follows:

$$
S=\sum_{i=1}^{n-1} \sum_{j=i+1}^{n} \operatorname{Sgn}\left(x_{i}-x_{j}\right)
$$

$$
\operatorname{Sgn}\left(x_{i}-x_{j}\right)= \begin{cases}1 & \text { if } x_{i}-x_{j}>0 \\ 0 & \text { if } x_{i}-x_{j}=0 \\ -1 & \text { if } x_{i}-x_{j}<0\end{cases}
$$

$$
\begin{aligned}
& V(S)=\frac{1}{18}\left[n(n-1)(2 n+5)-\sum_{p=1}^{q} t_{p}\left(t_{p}-1\right)\left(2 t_{p}\right.\right. \\
& -5)]
\end{aligned}
$$

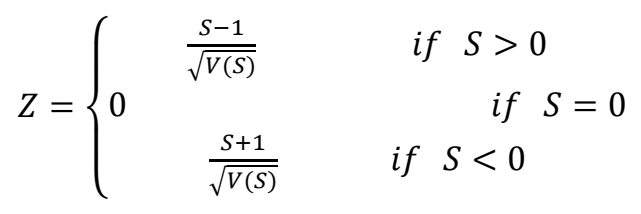

(4)

Where $x_{i}$ and $x_{j}$ are the annual values in year $i$ and $j, i>j$, respectively, $n$ is the length of time series, $t_{p}$ is the number of ties for pth value, and $q$ is the number of tied values. Positive $Z$ values indicate an upward trend and negative $Z$ values indicate downward trend. If $|\mathrm{Z}|>Z_{1-\alpha / 2}$ , $\left(\mathrm{H}_{0}\right)$ is rejected and statistically significant trend exist in hydrologic time series. The critical value 
of $Z_{1-\alpha / 2}$ for $\mathrm{p}$ value of 0.05 from the standard normal table is 1.96 .

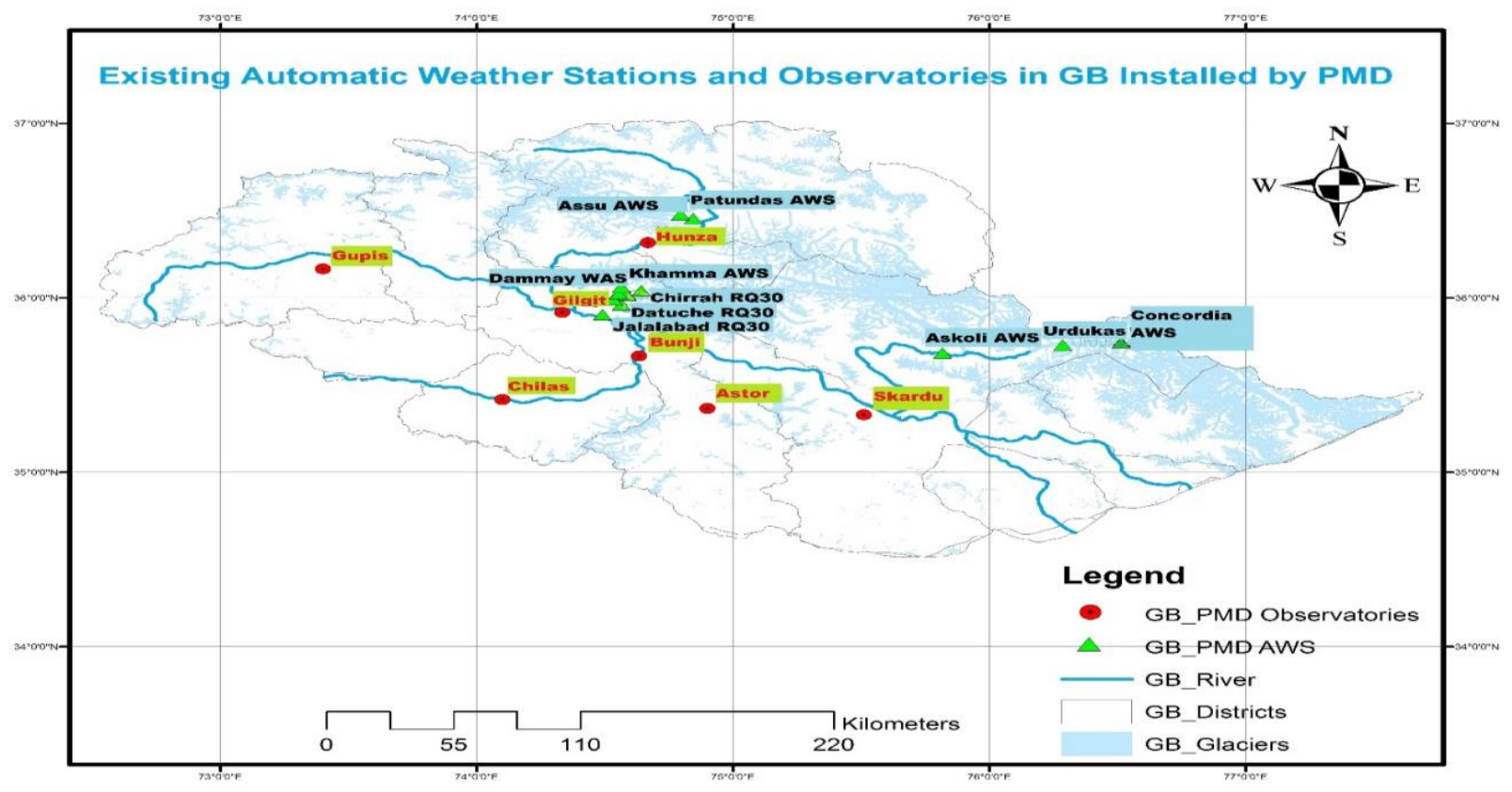

Fig. 1: Study Area and Location of the Meteorological Stations

\subsection{Sen's test}

To estimate the true slope of an existing trend (change per year) the Sen's nonparametric test is used [8]. In this study this method was used to estimate the magnitude of trend in the time series data:

$$
T=\frac{x_{j}-x_{k}}{j-k}
$$

In this equation, $x_{j}$ and $x_{k}$ represent data values at time $j$ and $k$, respectively. Consider

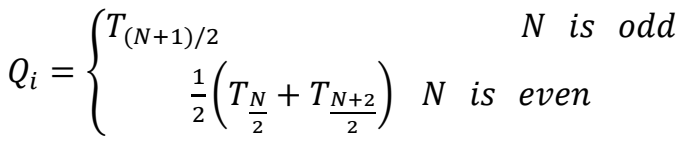

(6)

A positive $Q_{i}$ value represents an increasing trend; a negative $Q_{i}$ value represents a decreasing trend over time.

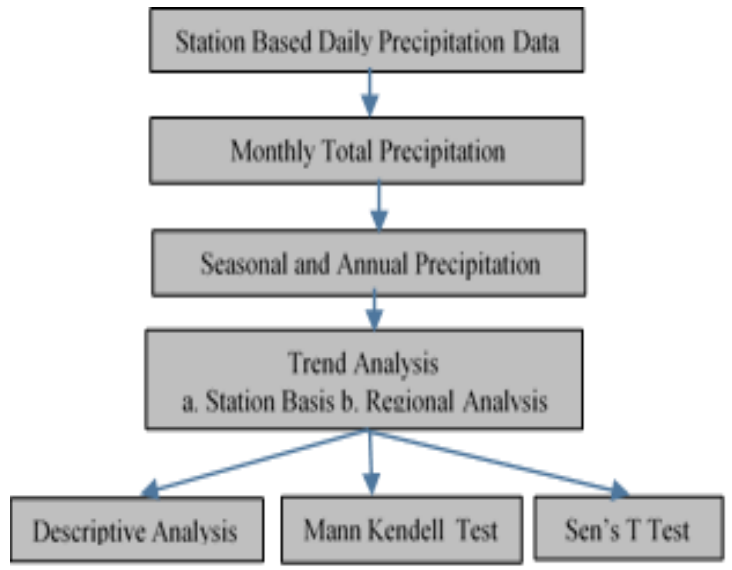

Fig. 2: The Stepwise Data Organization and the Analytical Tools Used in this Study.

For detecting and estimating trends in the time series Mann-Kendall and Sen's tests were performed, using Microsoft Excel template MAKESENS, which was developed by the Finnish Meteorological Department. MAKESENS is a widely used software for detecting and researching precipitation trends [4, 5]. For this study we divided the seasons of $G B$ into four 
categories. Table 2 describes the seasons and respective months.

Table 2: Seasons of Gilgit-Baltistan

\begin{tabular}{|l|l|}
\hline Seasons & Months \\
\hline $\begin{array}{l}\text { Winter } \\
\text { Season }\end{array}$ & $\begin{array}{l}\text { November, December, January, } \\
\text { February, }\end{array}$ \\
\hline Spring & March April, May \\
\hline Summer & June, July, August, September \\
\hline Autumn & October, November \\
\hline
\end{tabular}

\section{RESULTS}

\subsection{Station Basis}

\subsubsection{Increasing Trend of Annual \\ Precipitation}

Table 3 shows that in the region of GB the annual mean precipitation varies by location. During the period from 1980 to 2012 the annual mean precipitation varies from 148 to $485 \mathrm{~mm}$. Highest precipitation was recorded in Astor and the lowest in Gilgit.
Mann-Kendall test results revealed upward trend in annual precipitation at five weather stations i.e. Bunji, Chilas, Gilgit, Gupis and Skardu, and a downward trend of annual precipitation at Astor. Annual precipitation is increasing significantly at Gupis with a rate of $7.348 \mathrm{~mm}$ /year (Table 4).

\subsubsection{Seasonal Trends}

Seasonal trend of mean precipitation in $G B$ for 33 years (1980-2012) is summarizes in Figure 3. The figure shows that the highest amount of precipitation occurs during winter and lowest during autumn seasons. During winter the mean precipitation varies from 39 to $203 \mathrm{~mm}$ and in spring season it varies between 49 to $142 \mathrm{~mm}$ (Table 5). Being a winter dominant region, the highest amount of precipitation occurred during the winter season. As compare to the other parts of Pakistan, GB receives less precipitation in the summer season. During summer the amount of precipitation varies between 35 to $75 \mathrm{~mm}$ (Table 5).

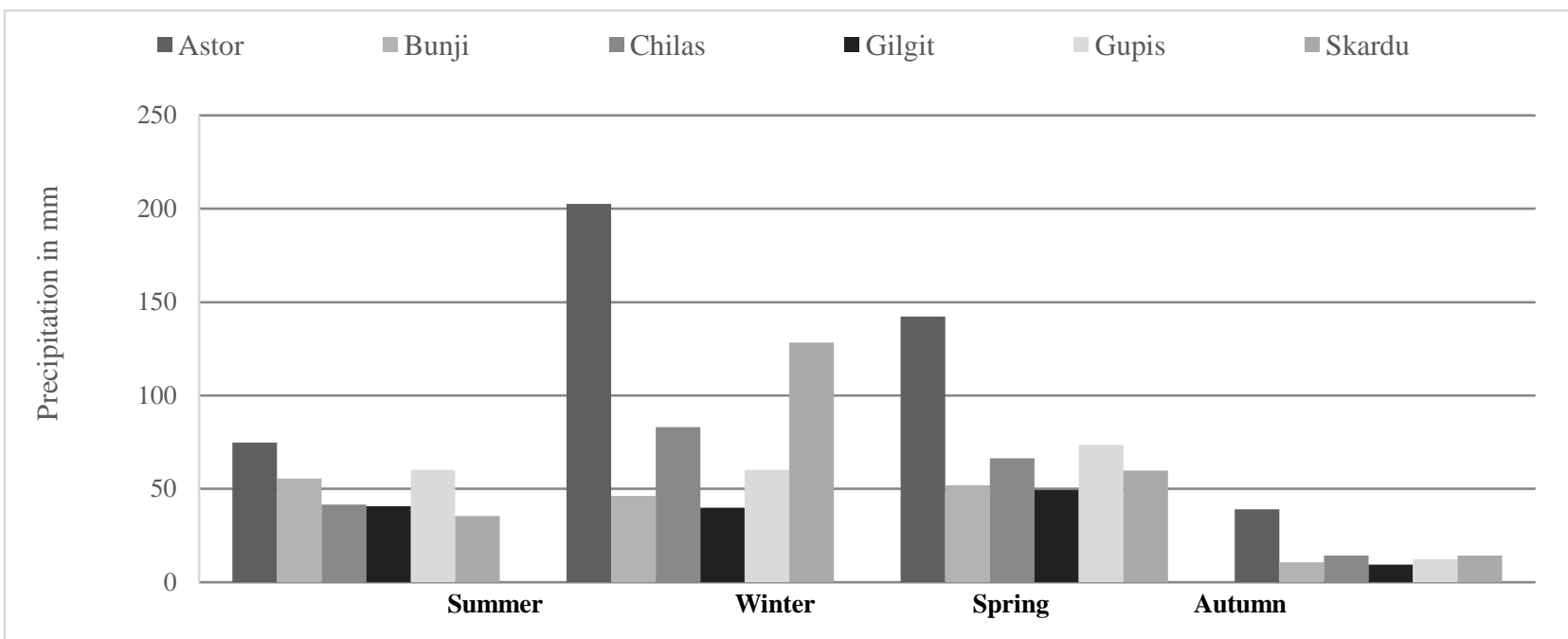

Fig. 3: Seasonal Trend of Precipitation in GB 
Table 3: Descriptive Statistics of the Annual Precipitation in GB for the period 1980-2012

\begin{tabular}{|c|c|c|c|c|}
\hline \multirow[t]{2}{*}{ Stations } & \multirow{2}{*}{$\begin{array}{l}\text { Mean } \\
\text { Precipitation } \\
(\mathrm{mm})\end{array}$} & \multirow[t]{2}{*}{ Std.Dev. } & \multicolumn{2}{|c|}{$\begin{array}{l}\text { Range Precipitation } \\
(\mathrm{mm})\end{array}$} \\
\hline & & & Min & $\operatorname{Max}$ \\
\hline Astor & 484.83 & 137.51 & 248.4 & 887.0 \\
\hline Bunji & 167.12 & 68.18 & 63.2 & 339.8 \\
\hline Chilas & 182.57 & 99.70 & 55.1 & 573.4 \\
\hline Gilgit & 148.23 & 56.62 & 67.5 & 300.9 \\
\hline Gupis & 212.15 & 169.38 & 63.0 & 683.0 \\
\hline Skardu & 267.15 & 213.68 & 87.0 & 1334.0 \\
\hline
\end{tabular}

Table 4: Mann-Kendall and Sen's Test Results of Annual Precipitation Trend for the Six Stations

\begin{tabular}{|c|c|c|c|l|}
\hline Stations & $\begin{array}{l}\text { MK Test } \\
(\text { Test Z) }\end{array}$ & Trend & Result & $\begin{array}{l}\text { Sen's Slope } \\
\text { Estimate Change in } \\
\text { Precipitation } \\
(\mathrm{mm} / \mathrm{y})\end{array}$ \\
\hline Astor & -1.13 & $\boldsymbol{\nabla}$ & NS & -3.055 \\
\hline Bunji & 0.51 & $\boldsymbol{\Lambda}$ & NS & 0.716 \\
\hline Chilas & 0.85 & $\boldsymbol{\Lambda}$ & NS & 0.756 \\
\hline Gilgit & 1.13 & $\boldsymbol{\Lambda}$ & NS & 1.309 \\
\hline Gupis & 3.46 & $\boldsymbol{\Lambda}$ & Sig. & 7.348 \\
\hline Skardu & 0.95 & $\boldsymbol{\Lambda}$ & NS & 1.756 \\
\hline
\end{tabular}

$\mathrm{mm}=$ Millimeter; MK: Mann-Kendall; NS: Not

Significant; Sig.: Significant; $\uparrow:$ Upward; $\downarrow$ :Downward

There is an upward trend of precipitation during summer season in the whole of GB region which clearly shows the approach of monsoon rain in this region. Spring rainfall is also increasing in Gilgit, Gupis and Skardu and it is decreasing in Astor, Bunji and Chilas. Winter precipitation is increasing at all the stations except Astor and Chilas where it is decreasing non-significantly. In Gupis the winter precipitation is significantly increasing with an increasing rate of 2.15 $\mathrm{mm} /$ year.
Table 5: Seasonal Mean, Standard Deviation and Range of Precipitation at Various Stations

\begin{tabular}{|c|c|c|c|c|c|}
\hline \multirow[t]{2}{*}{ Stations } & \multirow[t]{2}{*}{ Seasons } & \multirow{2}{*}{$\begin{array}{l}\text { Mean } \\
\text { Precip } \\
\text { itation } \\
(\mathrm{mm})\end{array}$} & \multirow{2}{*}{$\begin{array}{l}\text { Std. } \\
\text { Dev. } \\
\text { Precipi } \\
\text { tation } \\
(\mathrm{mm})\end{array}$} & \multicolumn{2}{|c|}{$\begin{array}{l}\text { Range } \\
\text { Precipitation } \\
(\mathrm{mm})\end{array}$} \\
\hline & & & & Min & Max \\
\hline \multirow[t]{4}{*}{ Astor } & Winter & 202.57 & 83.16 & 43.3 & 381.5 \\
\hline & Spring & 142.33 & 84.61 & 26.4 & 344.9 \\
\hline & Summer & 74.83 & 40.57 & 18.1 & 201.6 \\
\hline & Autumn & 39.09 & 41.85 & 0.6 & 170.6 \\
\hline \multirow[t]{4}{*}{ Bunji } & Winter & 46.24 & 31.19 & 5.7 & 126.7 \\
\hline & Spring & 51.90 & 40.43 & 6.5 & 144.3 \\
\hline & Summer & 55.63 & 33.46 & 0.0 & 138.0 \\
\hline & Autumn & 10.66 & 22.79 & 0.0 & 124.0 \\
\hline \multirow[t]{4}{*}{ Chilas } & Winter & 82.97 & 42.88 & 16.8 & 180.3 \\
\hline & Spring & 66.38 & 14.24 & 0.1 & 263.5 \\
\hline & Summer & 41.68 & 31.80 & 3.0 & 152.0 \\
\hline & Autumn & 14.24 & 28.13 & 0.0 & 146.2 \\
\hline \multirow[t]{4}{*}{ Gilgit } & Winter & 39.82 & 21.44 & 7.5 & 108.1 \\
\hline & Spring & 49.36 & 34.70 & 4.1 & 116.9 \\
\hline & Summer & 40.66 & 25.15 & 11.5 & 121.0 \\
\hline & Autumn & 9.40 & 18.34 & 0.0 & 102.4 \\
\hline \multirow[t]{4}{*}{ Gupis } & Winter & 60.28 & 53.55 & 0.0 & 222.3 \\
\hline & Spring & 73.59 & 95.11 & 0.0 & 410.9 \\
\hline & Summer & 60.19 & 50.17 & 2.3 & 182.4 \\
\hline & Autumn & 12.34 & 21.74 & 0.0 & 109.7 \\
\hline \multirow[t]{2}{*}{ Skardu } & Winter & 128.32 & 68.37 & 39.2 & 263.0 \\
\hline & Spring & 59.73 & 55.67 & 3.0 & 218.0 \\
\hline
\end{tabular}




\begin{tabular}{|r|r|r|r|r|r|}
\hline & Summer & 35.46 & 20.63 & 0.6 & 94.0 \\
\cline { 2 - 6 } & Autumn & 14.29 & 25.24 & 0.0 & 114.5 \\
\hline
\end{tabular}

Table 6: Seasonal Precipitation in Gilgit-Baltistan

\begin{tabular}{|r|r|l|l|r|r|}
\hline Region & Seasons & \multicolumn{1}{l|}{$\begin{array}{l}\text { Mean } \\
\text { Precipitatio } \\
\mathrm{n}(\mathrm{mm})\end{array}$} & $\begin{array}{l}\text { Std. } \\
\text { Dev. }\end{array}$ & \multicolumn{2}{|l|}{\begin{tabular}{l}
\multicolumn{2}{l|}{ Pange } \\
Precipitation
\end{tabular}} \\
\cline { 4 - 7 }$(\mathrm{mm})$
\end{tabular}

Table 7: Trend of Seasonal Precipitation of all Six Stations

\begin{tabular}{|c|c|c|c|c|c|}
\hline $\begin{array}{r}\text { Station } \\
\mathrm{s}\end{array}$ & Seasons & $\begin{array}{l}\text { MK Test } \\
\text { (Test Z) }\end{array}$ & Trend & $\begin{array}{c}\text { Resu } \\
\text { lt }\end{array}$ & $\begin{array}{l}\text { Sen's Slope } \\
\text { Estimate } \\
\text { Change in } \\
\text { Precipitatio } \\
\mathrm{n}(\mathrm{mm} / \mathrm{y})\end{array}$ \\
\hline \multirow[t]{4}{*}{ Astor } & Winter & -0.08 & $\downarrow$ & NS & -0.15 \\
\hline & Spring & -0.33 & $\downarrow$ & NS & -0.39 \\
\hline & Summer & 0.88 & 4 & NS & 0.53 \\
\hline & Autumn & -1.27 & $\downarrow$ & NS & -0.57 \\
\hline \multirow[t]{4}{*}{ Bunji } & Winter & 0.82 & 4 & NS & 0.42 \\
\hline & Spring & -0.50 & $\downarrow$ & NS & -0.18 \\
\hline & Summer & 0.93 & $\uparrow$ & NS & 0.60 \\
\hline & Autumn & 0.30 & 4 & NS & 0.00 \\
\hline \multirow[t]{4}{*}{ Chilas } & Winter & -1.12 & $\downarrow$ & NS & -1.03 \\
\hline & Spring & -0.64 & $\downarrow$ & NS & -0.33 \\
\hline & Summer & 1.07 & 4 & NS & 0.41 \\
\hline & Autumn & -0.08 & $\downarrow$ & NS & 0.00 \\
\hline \multirow[t]{2}{*}{ Gilgit } & Winter & 0.62 & 4 & NS & 0.32 \\
\hline & Spring & 0.08 & 4 & NS & 0.12 \\
\hline
\end{tabular}

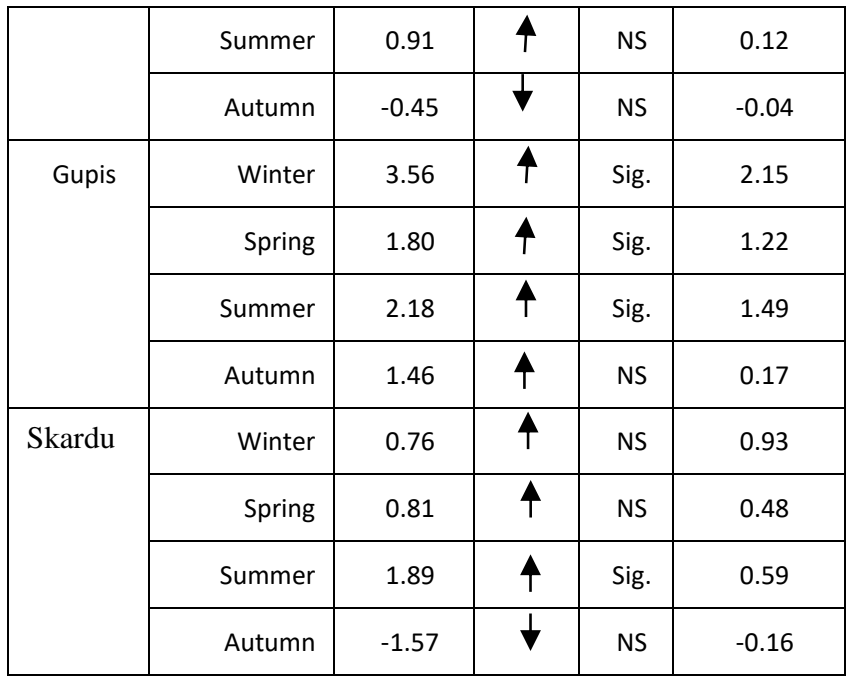

\subsection{Regional Trend Analysis}

Table 6 shows the seasonal means, respective standard deviations and the range precipitation in GB between the period 1980 and 2012. Seasonal percentages of mean precipitation revealed that forty percent of total annual precipitation occurs during winter season and $31 \%$ is received in the pre-monsoon season. Maximum amount of precipitation was observed during the winter and pre-monsoon.

Table 7 summarises the results of seasonal trend analysis of all stations. The Mann-Kendall test shows an upward trend of precipitation during the winter and summer seasons and downward trend in the autumn season. However the results are not statistically significant. Autumn season receives the lowest amount of precipitation showing the downward trend of precipitation which means that the region is becoming drier. On the basis of this trend analysis we can predict that $G B$ will receive more precipitation in future during winter and summer seasons.

\section{DISCUSSIONS}

Upstream water supply is crucial to sustain upstream water reservoir system, which are used to store and release water to downstream area when most needed. Indus Basin Irrigation System 
is the world largest irrigation network, which regulated through two major storage dams (Tarbela dam on Indus River and Mangla dam on the Jhelum River). Both are located in the upper Indus basin and are fed predominantly by melt water. Any change in upstream water supply to these dame will have profound effect on millions of people downstream [9]. This study investigated variability in monthly, seasonal and annual precipitation at 6 stations in the upper Indus basin over a 33- year study period (19802012). The mean annual precipitation at different stations showed considerable variation. Astor showed negative trend (decreased precipitation over time) at $5 \%$ significance level in the annual precipitation series. This will affect the contribution of water flow in the Indus from Astor basin. At the same significance level (5\%), at the remaining stations, there was an increasing trend in the annual precipitation trend. The significant changes in seasonal and annual precipitation over time was detected at Gupis station.

These study results follow the same statistical trend by Salma Khalid et al. [10] Hartmann et al. [11] for Indus River basin. Findings of this study were consistent with results from Imran [12], Stein Baver [13], Rasul [14], Dimri [15] wherein they found statistically significant increasing trends in winter precipitation for northern area of Pakistan. These deviations in precipitation trends may bring more water related disasters such as drought and flood in the near future.

\section{CONCLUSIONS}

Following conclusion can be deduced from the study:

seasons; at $214 \mathrm{~mm}$ and $250 \mathrm{~mm}$ respectively. Twenty two percent of the total mean precipitation occurs during summer season. The lowest precipitation occurs during the autumn season i.e. $7 \%$ of the total annual precipitation.

- Total annual precipitation in GB has increased. However, the trend is not statistically significant.

- In GB, $40 \%$ of the total annual precipitation was received in the winter season. The spring and summer season received $31 \%$ and $22 \%$ of the total precipitation respectively. Autumn season received the lowest amount of precipitation i.e. $7 \%$ of the annual precipitation.

- Autumn precipitation trend was decreasing in almost all the areas of GB and this season is getting drier.

- $G B$ is likely to receive more precipitation in the winter and summer seasons.

\section{ACKNOWLEDGEMENT}

I would like to express our sincere gratitude and appreciation to the Pakistan Meteorological Department (PMD) for providing data and valuable information.

\section{REFERENCES}

[1] G. Rasul, A. Mahmood, A. Sadiq and S.I. Khan, "Vulnerability of the Indus delta to climate change in Pakistan", Pakistan Journal of Meteorology, vol. 8, issue. 16, pp.89-107, 2012.

[2] G. Naheed and D.H. Kazmi, "Seasonal variation of rainy days in Pakistan", Pakistan Journal of Meteorology, vol. 9, issue. 18, pp. 9-13, 2013.

[3] M. Raza, D. Hussain, G. Rasul, M. Akbar and G. Raza, "Variation of surface temperature and precipitation in Gilgit-Baltistan (GB), Pakistan from 1955 to 2010", Journal of Biodiversity and Environmental Sciences, vol. 6, no. 2, pp. 67-73, 2015. 
[4] Ahmad, D. Tang, T.F. Wang, M. Wang and B. Wagan, "Precipitation trends over time using Mann-Kendall and Spearman's rho test in Swat river basin, Pakistan", Advances in Meteorology, vol. 2015, 2015.

[5] Finnish Meteorological Institutes, MAKESENSApplication for trend calculation [Internet], Finnish Meteorological Institutes. Available from http://en.ilmatieteenlaitos.fi/makesens [ Accessed 1st July 2015]

[6] H.B. Mann, "Nonparametric test against trend", Econometrica, vol. 13, pp.245-259, 1945.

[7] M.D. Rehman and M. Begum, "Application of non-parametric test for trend detection of rainfall in the largest Island of Bangladesh", ARPN Journal of Earth Sciences, vol. 2, pp. 4044, 2013.

[8] P.K. Sen, "Estimate of the regression coefficient based on Kendall's tau", Journal of the American Statistical Association, vol. 63, no. 324, pp. 1379-1389, 1968.

[9] W.W. Immerzeel, "Climate change will affect the Asian water towers", Science, vol. 328 , no. 1382, 2010.

[10] S. Khalid, M. Qasim, D. Farhan, "Hydrometeorological Characteristics of Indus River Basin at Extreme North of Pakistan. J Earth Sci Clim Change, vol. 5, no. 170, 2013.
[11] H. Hartmann and L. Andresky, "Flooding in the Indus river basin- A spatiotemporal analysis of precipitation records", Global and Planetary Change, vol. 107, pp. 25-35, 2013.

[12] A. Imran, Q. Zaman and M. Afzal, "Temporal trends in the peak monsoonal precipitation events over Northeast Pakistan", Pakistan Journal of Meteorology, vol. 10, no. 19, pp. 19-30, 2013.

[13] M.J. Steinbaver and J. Zeidler, "Climate change in the northern areas of Pakistan impact on glaciers, ecology and livelihood", WWF for Nature-Pakistan Gilgit Conservation and Information Center, 2008.

[14] G. Rasul, "Climate data and modelling analysis of the Indus region", Pakistan Meteorological Department (PMD), 2012, http://wwfpak.org/ccap/pdf/Climate Data Modelling\%20Analysis\%20of\%20the\%20Indus\%20Ecoregion.pd f.

[15] A.P. Dimri, "Surface and upper air fields during extreme winter precipitation over the western Himalayas", Pure and Applied Geophysics, vol. 163, no. 8, pp. 1679-1698, 2006.

Received: 24 April 2019. Revised/Accepted: 4 June 2019.

This work is licensed under a Creative Commons Attribution 4.0 International License. 